\title{
Jadranka Rebeka Anić
}

Institute of Social Sciences Ivo Pilar

Regional Centre Split, Croatia

\section{Filip Užarević}

Institute of Social Sciences Ivo Pilar

Zagreb, Croatia

\section{Ivan Puzek}

University of Zadar, Department of Sociology Originalni naučni rad

Zadar, Croatia

Datum prijema: 04.09.2021.

DOI: $10.18485 /$ rit.2022.20.37.1

\section{THE CORRELATION OF RELIGIOSITY AND TRADITIONALITY IN THE FIELD OF GENDER RELATIONS IN CROATIA AND SERBIA}

\begin{abstract}
Summary
In this article, we analyze the link between the discourses of two dominant religious communities - the Catholic Church in Croatia and the Orthodox Church in Serbia - and the attitudes and practices of the citizens of these two post-socialist states. In order to test this relationship, empirical data compiled on the citizens' level of religiosity, traditionality, and the gender division of labor in these societies were compared. The findings indicate that a correlation does exist between religiosity and traditionality in Croatia and Serbia; specifically, more religious individuals are still more traditional. Another correlation was found with the division of household work, but certain specificities emerge in relation to attitudes towards the division of labor between men and women.
\end{abstract}

Keywords: religiosity, traditionality, gender division of labor

\section{Introduction}

Croatia and Serbia are two former Yugoslav countries currently in transition and undergoing modernization. Despite the different ways in which societies in Croatia and Serbia developed following the dissolution of Yugoslavia and during the transition process (Croatia becoming a member of the EU, Serbia being awarded candidate status), they share certain tendencies which are relevant for the current topic. They commonly share a connection between the state and the dominant Church, despite the secular nature of these states (Dugalić 2007; Marinović 
2017; Vukomanović 2008, 2011). The revitalization of religion, that is, rising religiosity following the onset of democratic changes, as compared to the dominant situation during the socialist era (Vrcan 2001; Blagojević 2009, 2011; Gavrilović 2013 ) is also worth mentioning. Even though the process of increasing religiosity has undergone different phases, the number of believers in these two countries has stabilized at a very high level. ${ }^{1}$ Since both Croatia and Serbia are post-conflict societies, analyzing increased religiosity in them as a model of "cultural defense" (Bruce 1996, 96), that is, "the prevention of the destruction of the national, ethnic, local or some other culture", cannot be excluded. At the same time, attempts to retraditionalize gender relations were noted in both countries (Tomić-Koludrović and Kunac 2000; Šikić-Mićanović 2012; Vujadinović and Stanimirović 2017).

Existing sociological studies have determined that there are also significant differences between these societies regarding various aspects of the problem which was studied. The differences between the Catholic Church in Croatia and the Orthodox Church in Serbia can also be found in relation to types of believers. Despite the trend of a slight decrease in church religiosity (Nikodem and Zrinščak 2019, 371, 373), the dominant type of religiosity in Croatia is still "traditional, ecclesiastically oriented, collectivist religiosity [...], firmly tied to the nation and family, with a high degree of confessional identification"2 (Marinović Bobinac 2005, 342). In Serbia, the typology of religiosity is somewhat different (Blagojević 2009, 2011; Gavrilović 2013). There we find a religiosity dominated by traditionalism and ritual proportional to ecclesiology and intrinsic religiosity. Rituals are, at the same time, to a great extent occasional and tied to the holidays (Gavrilović 2013). Confessionalism and religiosity need not necessarily overlap, since confessionalism is in some cases connected to ethnic belonging and identity (Gavrilović 2013).

The increase in religiosity and confessional identity (Črpić and Zrinščak 2010; Gavrilović 2013) as well as institutional support for the strengthening of traditional church religiosity through a sequence of measures which strengthen the role of the Churches (Tomić-Koludrović and Petrić 2007; Đorđević 2005; Vukomanović 2008, Radić and Vukomanović 2013) are both important for the current topic due to the constant inclusion of religion in the production and reproduction of gender-related activities (Tomić-Koludrović 2015, 205). Dictated emancipation was characteristic of socialism (Leinert-Novosel 1999), which resulted in some improvements in the public life of women (employment, reproductive rights, education, engagement

1 According to the census from 2011 in which 86,28\% of the population in Croatia declared themselves Catholics (Croatian Bureau of Statistics 2011), while in Serbia 84,59\% declared themselves Orthodox Christian (Statistical Office of the Republic of Serbia, 2011).

2 All the translations included in the article are the authors' own. 
in political activities), while gender relations and roles within the family remained mainly traditional (Tomić-Koludrović and Kunac 2000). According to ecclesiastical discourse, communist ideology skirted the emancipation of women with the aim of destroying the traditional, Christian family in which a woman plays a key role in preserving the family, nation, and faith (Anić 2004, 43-44). It is therefore not surprising that family relations "in socialism reflected the strong impact of religious tradition, and that this impact could be felt during the period of transition as well" (Tomić-Koludrović 2015, 237). Research conducted in Croatia following the onset of democratic changes still "indicates that numerous declarative believers often do not accept $[\ldots]$ the concepts of masculinity and femininity advocated by the Catholic Church" (212-213), and the retraditionalization of society, which is reflected in rising religiosity and national exclusivism, does not occur at the expense of modernization, which is reflected in the acceptance of gender equality and the continued decrease in gender conservatism (Sekulić 2011, 58). In the case of Serbia, during her years of research Marina Blagojević Hughson reported the prevalence of repatriarchalization and retraditionalization, "which not only have very negative consequences for women, but for men as well, especially among the younger generations", exposing them to harmful lifestyles "with the aim of confirming an imaginary ideal of the 'real man', including the acceptance of dangerous extreme ideologies" (Hughson 2018, 108).

All this points to the need to analyze the relationship between religiosity and a conservative value orientation as it pertains to the gendered division of household work.

The basic aim of this article is to establish a connection between high levels of religiosity and the important role of the church and traditionality in the societies studied. The theoretical framework of the study is based on Inglehart's theory of social values. Traditional values are irrational, based on religion, national pride, obedience, and respect for authority (Inglehart 2000). Within this framework, the increase in religiosity on the territory of Serbia and Croatia was analyzed, as was the persistence of traditional values in these countries in the field of gender relations, since this schema might suggest that this occurrence will accompany the traditional complex (traditional family relations embedded in intra-family relations and roles). Generally speaking, since the 1960s, studies have confirmed that a high prevalence of religion in the public and private life of citizens goes hand in hand with a low level of tolerance towards abortion, divorce and homosexuality, higher marriage rates among younger people, respect for parental authority, and ascribing importance to family life. Research indicates that religiosity also affects attitudes towards gender roles in the family, and the status 
of authority in the family (Inglehart and Baker 2000; Bartkowski 2007; Stjepanović-Zaharijevski and Gavrilović 2010; Krstić et al. 2016).

Based on the analysis of quantitative data from the SCOPES ${ }^{3}$ and GENMOD projects, our aim is to evaluate the correlation between religiosity and traditionality, as well as their relationship with the gender division of household work in this article. The gender division of labor is only one of the aspects of family life which reflects the value orientation of the respondents. The determination of these relationships was motivated by increased religiosity, the highly public position of churches in these societies, as well as the omnipresent discourse of dominant churches which is effectively advocating for the traditionally present Christian and patriarchal model of family relations in these areas.

The first part of this article presents the social context in the societies studied, that is, the influence of the dominant churches on the state and society as a whole, as well as the gender discourse of the religious communities, that is, the patriarchal model which they protect as the foundation of family and social relations. The second part outlines the analysis and interpretation of the data obtained from the empirical study. In the final section, the findings and analyses are interpreted in the context of the theoretical provisions and existing interpretations of the phenomena studied.

\section{The relations between the state and church and the gender discourse of the dominant churches}

The Republic of Croatia is by its constitution defined as a secular state which guarantees freedom of religion and a neutral worldview. However, the basic tenet of the separation of Church and state was questioned by four international agreements between the Holy See and the Republic of Croatia in 1996 and 1998 (ratified in 1997 and 1998) (Marinović and Markešić 2012; Marinović 2017). The provisions of the Treaty between the Holy See and the Republic of Croatia in the field of Upbringing and Culture according to which "the system of upbringing and educational system in public preschool institutions and schools, including higher education centers as well" will "take into consideration the values of Christian ethics" (Treaty between the Holy See and the Republic of Croatia in the field of Upbringing and Culture 1997, Article 1.) are particularly problematic. The Catholic majority and the duty to adhere to the values of Christian ethics are often the arguments put forth by the Catholic Church when discussing topics in public, which can be

3 The research "Life Strategies and Survival Strategies of Households and Individuals in South-East European Societies in the Period of Economic Crisis" 2014-2016 SCOPES program was funded by the Swiss National Science Foundation. 
classified as belonging to the politics of morality (Bekić, 2013). These include issues of contraception and abortion, medically assisted insemination and miscarriage, the rights of same-sex unions, no work on Sundays, health, or sex education (Bekić 2013; Goldberger 2005, 417), the so-called "gender ideologies" (Anić 2017), and the ratification of the Council of Europe Convention on preventing and combating violence against women and domestic violence, known as the "Istanbul convention". As part of the discussions on "gender ideology", health/sex education and the ratification of the Istanbul convention, gender stereotypes and roles have been pointed out as particularly dangerous for the family (Anić 2019).

Through Vatican treaties, the Church has gained entry into numerous parts of the Croatian state system, into education, the military, and healthcare. At the same time, attempts have been made to sway public opinion in other ways as well, such as: statements made by the Croatian Bishop's Conference (CBC) organizations (in particular the Permanent Council of the $\mathrm{CBC}$ and the Justitia et pax Commission), statements made by individual bishops and theologians, the activities of Catholic associations, the politics of Catholic publishing houses, and the Catholic media, including pressures and threats such as the threat to deny the right to a sacrament to politicians who vote for the ratification of the "Istanbul convention" (D.I., 2018).

On the other hand, it is important to note that trust in the Catholic Church has decreased significantly over the past ten years. Specifically, the Church enjoyed the support of as many as $62.8 \%$ of citizens in 1999 compared to 2008 when this decreased to $52.4 \%$ while only $38.4 \%$ of citizens supported the Church in 2018 (Nikodem and Zrinščak 2019, 377).

The Constitution of the Republic of Serbia also defines it as a secular state. The church and any religious communities are separate from it. No religion can be established as the state religion, or as an obligatory one. "The church and religious communities are equal and free to independently determine their own internal organization, religious activities, to publicly perform religious ceremonies, to found religious schools, social and charity foundations and to manage them, in accordance with the law." (The Constitution of the Republic of Serbia 2006). This relationship is more precisely determined by the Law on Churches and Religious Communities of 2006. The aforementioned law emphasizes the specific role of the Serbian Orthodox Church (SOC) compared to other traditional religious communities:

"The Serbian Orthodox Church has had an exceptional historical, state-building and civilizational role in forming, preserving and developing the identity of the Serbian nation" (Law on Churches and Religious Communities of the Republic of Serbia, 2006). 
Furthermore, after October 5, 2000 ${ }^{4}$, the SOC began to offer a new ideological framework for state institutions, such as the military or educational institutions, filling out, at its own initiative, the ideological vacuum or emptiness which emerged following the breakup of communism (Radić and Vukomanović 2013). Religious education was reinstated in public schools in 2001, and the Faculty of Orthodox Theology included among the Serbian State Universities in 2004. The presence of a priest in military institutions is approved, and the SOC is a key factor in resolving the problem of Kosovo (Radić and Vukomanović 2013).

An important feature of the inclusion of the SOC in the public scene of Serbia is also the huge trust that the population has in this institution (it came in first in all the studies carried out over the past few years, then experienced a slight decrease and slid into second place after the military, going from $75 \%$ to $66 \%$ (Jovanović and Gavrilović 2012,139), which also indicates its increased influence on all the spheres of society and the necessity of a connection between political powers which count on achieving success with the SOC. The specific nature of the relationship between the SOC, society, and the Serbian state is that it is "burdened by the legacy of a symphony" and the important role of the SOC in preserving ethnic identity, for which it was credited and for which it is even now considered socially relevant. Even though declaring itself secular, Serbia is a state in which almost all public institutions and cities celebrate their patron saint days, and where St. Sava is celebrated in all schools, not just as an educator, but also as a saint, with clear elements of the Orthodox Christian cult. Its activity spreads from the sphere of education (religious education), via influence in the legal-political sphere to international relations and European integrations (Radić and Vukomanović 2013).

The SOC, according to its nature and its commitment to the national community, in its epistles and addresses discusses predominantly topics of national importance. In addition to certain long-standing issues, it is possible to encounter issues connected to current events and the social problems in Serbia: Kosovo and Metohi$\mathrm{ja}$ is a constant topic, as are the shrines of Kosovo, the relationship with Macedonia and the Montenegrin Orthodox Church, abortion (Pralica 2006), the duty of Serbian women to give birth (Đorić and Gavrilović 2006), the judgment that is passed on career women, and judgment on any uncertainty about giving birth. In the SOC, homosexuality has been treated as an illness and a moral deviancy (Jovanović, 2011, 710).

Both the Catholic and Orthodox Church stand for the so-called model of gender complementarity. According to that model, the differences between wom-

4 Overthrowing the rule of Slobodan Milošević, and the beginning of democratic changes in Serbia. 
en and men are not solely biological, but also essentialist. They are differences which are rooted in the very essence of God's creation of human nature and are reflected in the particular expression of individuality. According to that difference, masculinity is dominant, femininity is reflexive and responsive. These are hypotheses on which gender stereotypes are based. The gender relationship is explained as equality in dignity, differences in rights and roles (Lüdecke 2009, 183211; Butcher 2020; Vasilevich 2018).

Even though attempts have been made in both the Catholic and Orthodox theology to interpret male-female identities as unalterable and essentialist (Anić 2019; Vasilevich 2018; Kupari-Vuola 2020, 5), there is still a gradual acceptance that gender roles are susceptible to cultural-social influences. The changeability of male-female relations is gradually being accepted by Catholic teaching (Pope Francis 2016, no. 286); in Orthodoxy differences are imposed depending on whether the Orthodox communities are active in societies which are mostly Orthodox, or societies with a minority Orthodox population (Kupari-Vuola 2020, 8). At the same time, exposure to secularism, multiculturalism, and religious diversity can result in increasing flexibility or the strengthening of gender roles and norms. In post-communist societies such as Croatia and Serbia, the religious interpretation of gender is understood as opposition to communist ideology and the past, which can affect the strengthening of religiously prescribed norms and roles.

This is precisely the argument that is used by the anti-gender movement (Kuhar and Paternotte 2017) which has been developing in Croatia, especially since 2012, in Serbia since 2017 (Zaharijević 2018). The initiators and bearers of this movement are Catholic associations, which are intensely supported by the hierarchy and by theologians (Hodžić and Štulhofer 2017; Anić 2017). Both in the international and national anti-gender discourse, an important role is played by the defense of gender stereotypes. Specifically, as one of the dangers ascribed to "gender ideology", which originates in Marxist ideology (Peunić 2019), the deconstruction of gender stereotypes is understood as the destruction of Christian anthropology and the destruction of the family (Anić 2019). Still, considering that the entire discourse does not want to be portrayed as anti-feminist, there is avoidance of the outright questioning of the equality of women on the job market, or the sequential listing of male-female roles in family life.

This discourse based on gender essentialism assumptions is also supported by the sermons, epistles and addresses of the hierarchy in Croatia ${ }^{5}$ and by Catho-

5 The fundamental assumption in the sermons of Archbishop of the Archdiocese of Split-Makarska and of the Archbishop of the Archdiocese of Zagreb, which were published on the 
lic publishing houses, which publish books such as Udaj se i budi podložna (Get married and be subservient), Oženi se i umri za nju (Get married and die for her), etc. In workshops aimed at counselling married couples, men are advised to be more gentle with their women while women are encouraged to show their men respect (Ika 2020).

The gender discourse of the SOC also has an important impact on the attitudes of citizens in Serbia in terms of gender relations (Gavrilović 2013, 86). The SOC does not have a comprehensive social teaching, and so gender discourse can be deduced from an analysis of its various publications, books on religious teaching, epistles, various statements made by dignitaries, and texts published in the magazine "Pravoslavlje". Gender relations are often addressed by representatives of the SOC. The theory is based on the well-documented patriarchal concept which the SOC advocates (Simić 2014; Vujadinović 2017; Ranković, 2009). The SOC advocates divided social roles for boys and girls, which need to be developed through socialization (in brochures such as Šta treba da zna pravoslavna devojčica /What an Orthodox girl should know/, Šta treba da zna pravoslavni dečak /What an Orthodox boy should know). A woman needs to be both subservient and obedient at the same time (Vujadinović 2017). A woman needs to be devoted to her home and children, and needs to have a pronounced reproductive function; otherwise, she could be labeled a "careerist". "The church sees the role of mother as the central role of a woman, and her moral duty both before God and the national and religious collective" (Simić 2014). In the SOC there is a clear relationship between a woman and the nation which needs to be preserved through childbirth.

"The Church regards motherhood as a woman's main calling, her 'life mission'. The purpose of motherhood is to prolong and expand the family, nation and humanity. Consequently, the woman is the pillar of the family, a source of 'strength, joy and consolation' to her husband and children, a care giver and a

websites of these archdioceses is that "male and female gender are of equal (...) dignity, but are different in terms of gender, temperament and psyche" (Barišić 2018). Usually, when they talk about a woman, they speak of a woman-mother. Her features include gentleness, love, and selflessness. The woman-mother looks at things through her heart (Barišić 2018), her words are "more on the wave of love, mercy and kindness than on the sharp line of arguments, prohibitions and commands" (Barišić 2017c). According to divine providence "true femininity gives off an air of gentleness and kindness, sensitivity and intuition" (Barišić 2017b). A mother transfers to her children "the affective I" while the father transfers "the moral I" (Bozanić 2013). To the children, the father manifests "masculine humanity, positive assertiveness, and creative activity" (Barišić 2016). The father means "safety, decisiveness, venture, responsibility, and encouragement" (Barišić 2017b). The woman-mother is responsible for "the three corners of the household" and her greatest care should be shown around "the family table" and for the "sanctity of the home" (Barišić 2017a). Mary, the Mother of Jesus, is presented as a role model for women. Like Mary, these women need not be socially exposed in order to be able to influence social trends (Barišić 2017d). 
guardian of the ancestors' religious and moral values, including the traditions and customs of the family and the nation." (Đurić-Milovanović and Radić 2019, 15).

In both countries, despite their secular character, the two dominant religious communities have extensive opportunities for spreading their own gender discourse, one based on gender stereotypes, through various state institutions which educational ones, as well as through the media. Because there is a connection between religiosity and national identity, traditional family relationships, and the opposition of these relationships first towards the communist regime, and then towards the contemporary threat posed by "gender-ideology", it is possible to expect a strong correlation between religiosity, traditionality, and gender practices. Still, it was noted that even within these religious communities more people began questioning stereotypical roles which were affected by the social processes of modernization, in turn leading to a decrease in the trust in the Church. What was also noted was the possibility for inconsistency and a lack of congruence between religiosity, traditionality, and practices pertaining to household work.

\section{The researched relations, the methodology and the sample}

Beginning with the role of the Catholic and Orthodox Church in Croatia and Serbia, and their gender discourse which supports gender stereotypes, and further based on the quantitative data from the SCOPES and GENMOD projects, the research questions are as follows:

1. Are more religious people also more traditionally oriented?

2. Do higher levels of religiosity and traditionality lead to a more traditional relationship towards the division of household work?

The core data analyses used in the article were based on data from the SCOPES survey carried out from January to March 2015, on national proportional samples of 1,000 respondents each in Serbia $(n=1000,54 \%$ women $)$ and Croatia ( $\mathrm{n}=1000,58 \%$ women). The survey was implemented by a professional agency (IPSOS ADRIA in both countries) and based on face-to-face interviews as part of the SCOPES project.

\section{The measuring instruments}

Traditionalism. The questionnaire included 17 items measuring traditionalism. The instrument used in this research did not contain all the items used by Inglehart and his co-researchers when evaluating their hypotheses on the relationships between social relations and values, items 
which are traditionally used in research (EVS) to evaluate the presence of traditional attitudes (Inglehart and Baker 2000). An example item which was used in the study reads: "Women should play a greater role in leadership positions in society, the business world, culture, and politics" (reversely coded; see Appendix Table 1 for a full list of items). The index of traditionalism was the average of the scores on the 17 items. $^{6}$

Religiosity. The religiosity index consisted of three items, measuring (1) frequency of religious ceremony attendance, (2) frequency of prayer, and (3) the degree to which the respondent felt that religion was a personal source of strength and support. ${ }^{7}$ The index of religiosity was the average score on these items.

Gender division of household work. To investigate how housework is distributed relative to gender in Croatia and Serbia, the respondents were offered a list of household chores and were asked to list the person or persons predominantly in charge of each of the chores. The list of chores can be found in Appendix Table 3. The responses were open-ended. The coding of the responses from the open-ended text to appropriate categories based on gender was partially automated by using regular expressions to match corresponding keywords such as majka (mother), suprug (husband), brat (brother), etc., in the first step. Due to the relatively high number of input errors and some ambiguous answers, the coding was re-checked manually in the second step. ${ }^{8}$ For each chore, the responses were subsequently recoded so that 1 indicates a woman as being in charge of that chore (e.g. the mother, the respondent if she is female, the daughter, etc.), and -1 indicates a man as being in charge of the chore (e.g. the father, the respondent if he is male, the son, etc.). The responses which did not fit those categories were identified as missing

6 The traditionalism scale was created by, firstly, transforming all the items on a scale from 1 to 7 (for the original scale see Appendix Table 1), and reversing some of the items so that the higher result indicated higher levels of traditionalism. For the traditionalism index, as well as the other indices in this text, in case of missing data in some of the items, the available obtained data for that respondent was averaged.

7 The item reflecting the degree to which the respondent felt that religion was a personal source of strength and support, originally on a scale from 1 to 10 , was transformed to a scale from 1 to 6 , to correspond to the other items (see Appendix Table 2).

8 Due to the open-ended nature of the responses, many inputs were apparent typos/errors, or had ambiguous meaning. In such instances their coding was judged on a case-to-case basis, for which a degree of subjectivity could not be avoided, potentially affecting the reliability of the findings. For the same reasons (coding issues), the last four items in Appendix Table 3 were not used at all in the analyses. 
(e.g. if the respondent listed multiple people as being responsible for that chore).

To obtain a single index of the gender division of household work, we computed the mean score on the items corresponding to the chores typically perceived as feminine, i.e. buying groceries, washing the dishes, vacuuming, spring cleaning, washing the windows, ironing, washing the laundry, and cooking. The other items were not included in the analyses (except in Figures 2 and 3).

\section{Results}

The following tables present the results of the empirical study which indicate the presence and type of correlation between the occurrences which were studied.

We will first present the values of religiosity and traditionality for both countries. Then we will present the correlation between religiosity and traditionality, and finally the mutual connection between religiosity, traditionality, and the household division of labor.

\section{Table 1. Traditionalism and religiosity in \\ Croatia and Serbia (SCOPES data).}

\begin{tabular}{|c|c|c|c|c|c|}
\hline & Croatia & Serbia & \multicolumn{3}{|c|}{ Comparisons } \\
\hline Variables & $\mathrm{M}(\mathrm{SD}), \mathrm{N}$ & $\mathrm{M}(\mathrm{SD}), \mathrm{N}$ & $\mathrm{F}$ & $\mathrm{p}$ & $\eta^{2}$ \\
\hline Traditionalism & $4.65(0.73), 1000$ & $4.97(0.74), 997$ & 97.91 & .000 & 0.05 \\
\hline Religiosity & $3.61(1.47), 1000$ & $2.61(1.13), 1000$ & 293.14 & .000 & 0.13 \\
\hline
\end{tabular}

Table 1 outlines the descriptive statistics of the traditionalism and religiosity scales by country, as well as comparisons between Croatia and Serbia. The results suggest that respondents from Serbia tended to score higher on traditionalism compared to respondents from Croatia. The respondents from Croatia, on the other hand, tended to be more religious than respondents from Serbia.

Comparisons between the two countries in terms of religiosity were of particular interest. Figure 1 presents the distributions of the three items reflecting religiosity in Croatia and Serbia. As can be seen, there is a tendency among the respondents from Croatia to score higher than the respondents from Serbia on all three items. 
D. Gavrilović, J. R. Anić, F. Užarević, I. Puzek: The correlation of religiosity and...
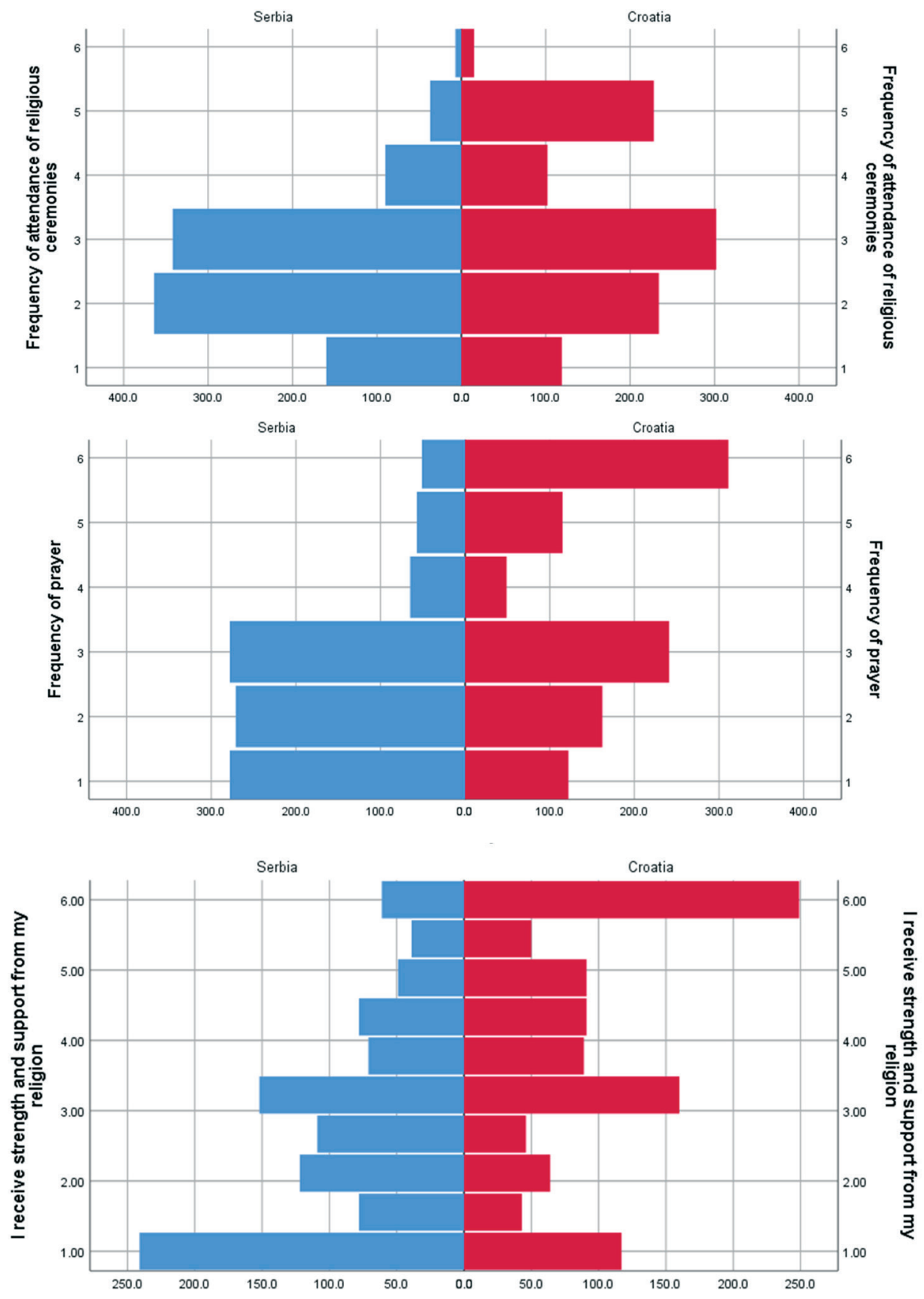

Figure 1. Histograms for the three items measuring religiosity for

Croatia and Serbia (SCOPES data). 
To gain better insight into the relationships between religiosity and traditionalism in each country, we divided the respondents into four groups of roughly similar size depending on their religiosity scores, and the same was done based on the traditionalism scale. The four groups for each scale included approximately $25 \%$ of the respondents scoring the lowest, approximately $25 \%$ scoring the highest, and two groups in between. The cross-tabulation of the two variables can be seen in Table 2 .

The chi-square tests of the relationship between religiosity and traditionalism, based on the results presented in Table 2, yielded statistically significant results both for the respondents from Croatia, $\chi^{2}(9,1000)=154.02, \mathrm{p}<.001$, and the respondents from Serbia $\chi^{2}(9,997)=110.28, \mathrm{p}<.001$. The results suggest that the proportion of those highly (vs. less) religious was over-represented among highly traditional people, while the proportion of those less (vs. highly) religious was over-represented among the less traditional people in both Serbia and Croatia. These findings show that a relationship between religiosity and traditionality does exist in these two countries. This indicates that we cannot expect the religious people living in them to become open to a more modern approach to various segments of life.

Table 2. Cross tabulation of religiosity and traditionalism, with the respondents split into approximate quarters depending on their scores on the religiosity and traditionalism scale (SCOPES data).

\begin{tabular}{|c|c|c|c|c|c|c|}
\hline \multicolumn{2}{|c|}{$\begin{array}{l}\text { Croatia } \\
\text { Traditionalism }\end{array}$} & \multicolumn{5}{|c|}{ Religiosity } \\
\hline & & $\begin{array}{l}\text { Scoring } \\
\text { Lowest }\end{array}$ & $\begin{array}{l}\text { Scoring } \\
\text { Mid- } \\
\text { Low }\end{array}$ & $\begin{array}{c}\text { Scoring } \\
\text { Mid- } \\
\text { High }\end{array}$ & $\begin{array}{l}\text { Scoring } \\
\text { Highest }\end{array}$ & Total \\
\hline \multirow{2}{*}{$\begin{array}{l}\text { Scoring } \\
\text { Lowest }\end{array}$} & Count & $122 \mathrm{a}$ & $64 b$ & $37 \mathrm{c}$ & $30 \mathrm{c}$ & 253 \\
\hline & $\%$ within religiosity & $45.4 \%$ & $25.8 \%$ & $15.4 \%$ & $12.4 \%$ & $25.3 \%$ \\
\hline \multirow{2}{*}{$\begin{array}{l}\text { Scoring } \\
\text { Mid-Low }\end{array}$} & Count & $81 \mathrm{a}$ & $69 a$ & $63 a$ & $35 b$ & 248 \\
\hline & $\%$ within religiosity & $30.1 \%$ & $27.8 \%$ & $26.1 \%$ & $14.5 \%$ & $24.8 \%$ \\
\hline \multirow{2}{*}{$\begin{array}{l}\text { Scoring } \\
\text { Mid-High }\end{array}$} & Count & $40 \mathrm{a}$ & $63 b$ & $69 b$ & $78 b$ & 250 \\
\hline & $\%$ within religiosity & $14.9 \%$ & $25.4 \%$ & $28.6 \%$ & $32.2 \%$ & $25.0 \%$ \\
\hline \multirow{2}{*}{$\begin{array}{l}\text { Scoring } \\
\text { Highest }\end{array}$} & Count & $26 a$ & $52 b$ & $72 \mathrm{c}$ & $99 d$ & 249 \\
\hline & $\%$ within religiosity & $9.7 \%$ & $21.0 \%$ & $29.9 \%$ & $40.9 \%$ & $24.9 \%$ \\
\hline \multirow{2}{*}{ Total } & Count & 269 & 248 & 241 & 242 & 1000 \\
\hline & $\%$ within religiosity & $100.0 \%$ & $100.0 \%$ & $100.0 \%$ & $100.0 \%$ & $100.0 \%$ \\
\hline
\end{tabular}




\begin{tabular}{|c|c|c|c|c|c|c|}
\hline \multicolumn{2}{|c|}{$\begin{array}{l}\text { Serbia } \\
\text { Traditionalism }\end{array}$} & \multicolumn{5}{|c|}{ Religiosity } \\
\hline & & $\begin{array}{l}\text { Scoring } \\
\text { Lowest }\end{array}$ & $\begin{array}{c}\text { Scoring } \\
\text { Mid- } \\
\text { Low }\end{array}$ & $\begin{array}{c}\text { Scoring } \\
\text { Mid- } \\
\text { High }\end{array}$ & $\begin{array}{l}\text { Scoring } \\
\text { Highest }\end{array}$ & Total \\
\hline \multirow{2}{*}{$\begin{array}{l}\text { Scoring } \\
\text { Lowest }\end{array}$} & Count & $123 a$ & $49 b$ & $52 \mathrm{~b}$ & $29 \mathrm{c}$ & 253 \\
\hline & $\%$ within religiosity & $46.2 \%$ & $21.0 \%$ & $20.5 \%$ & $11.9 \%$ & $25.4 \%$ \\
\hline \multirow{2}{*}{$\begin{array}{l}\text { Scoring } \\
\text { Mid-Low }\end{array}$} & Count & $68 \mathrm{a}$ & $62 \mathrm{a}$ & $59 a$ & $57 \mathrm{a}$ & 246 \\
\hline & $\%$ within religiosity & $25.6 \%$ & $26.6 \%$ & $23.2 \%$ & $23.4 \%$ & $24.7 \%$ \\
\hline \multirow{2}{*}{$\begin{array}{l}\text { Scoring } \\
\text { Mid-High }\end{array}$} & Count & $45 a$ & $59 b$ & $75 b$ & $72 b$ & 251 \\
\hline & $\%$ within religiosity & $16.9 \%$ & $25.3 \%$ & $29.5 \%$ & $29.5 \%$ & $25.2 \%$ \\
\hline \multirow{2}{*}{$\begin{array}{l}\text { Scoring } \\
\text { Highest }\end{array}$} & Count & $30 \mathrm{a}$ & $63 b, c$ & $68 \mathrm{c}$ & $86 \mathrm{~b}$ & 247 \\
\hline & $\%$ within religiosity & $11.3 \%$ & $27.0 \%$ & $26.8 \%$ & $35.2 \%$ & $24.8 \%$ \\
\hline \multirow{2}{*}{ Total } & Count & 266 & 233 & 254 & 244 & 997 \\
\hline & $\%$ within religiosity & $100.0 \%$ & $100.0 \%$ & $100.0 \%$ & $100.0 \%$ & $100.0 \%$ \\
\hline
\end{tabular}

Note. Each subscript letter denotes a subset of the religiosity categories whose column proportions do not differ significantly from each other at the .05 level.

The following graphs indicate that there is a clear division of household work in terms of male and female chores in Croatia and Serbia. The distribution of household work is almost identical in these two countries.

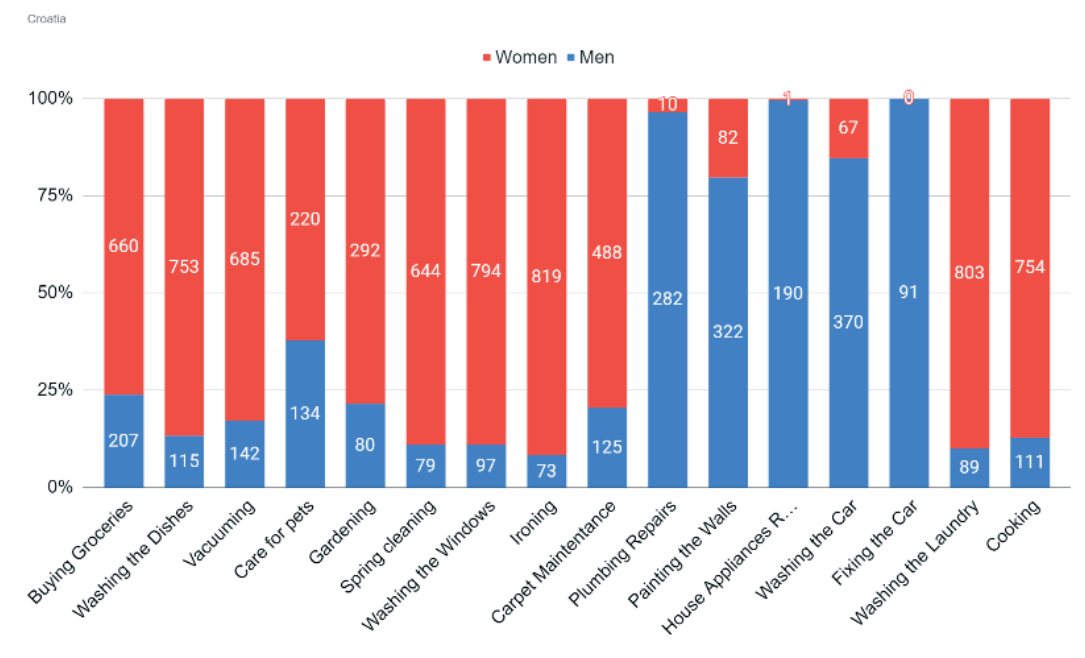

Figure 2. The division of household work in Croatia. 


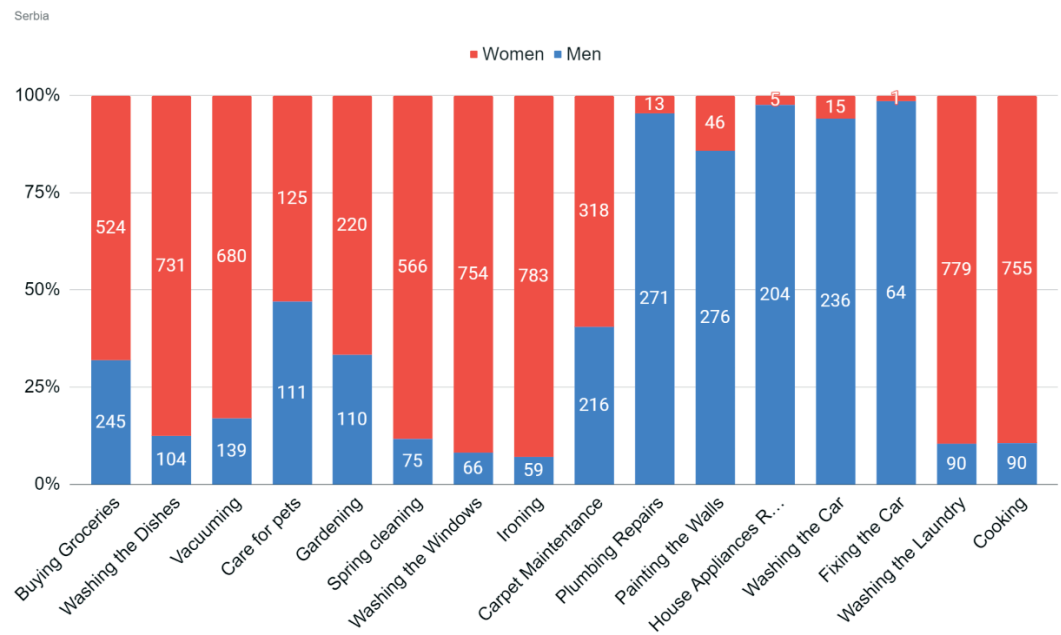

Figure 3. The division of household work in Serbia.

We further compared the respondents, divided into four groups based on their level of religiosity, in terms of their scores on traditionalism and division of housework (reporting that women are more frequently in charge of various household chores compared to men). As can be seen from Table 3, there seems to be a hierarchy with scores on the traditionalism scale increasing with an increase in the level of religiosity in both Serbia and Croatia. Similarly, the frequency of reporting that women are in charge of various household chores increased with rising religiosity, at least in Croatia (in Serbia, the ANOVA results were not significant).

Table 3. Traditionalism and division of household work by levels of religiosity.

\begin{tabular}{|l|l|l|}
\hline Croatia & Traditionalism scale & Household work division (women) \\
\hline Religiosity & M (SD), N & M (SD), N \\
\hline Scoring Lowest & $4.25(0.69), 269$ & $0.61(0.71), 264$ \\
\hline Scoring Mid-Low & $4.59(0.67), 248$ & $0.68(0.66), 244$ \\
\hline Scoring Mid-High & $4.80(0.67), 241$ & $0.79(0.51), 238$ \\
\hline Scoring Highest & $5.00(0.66), 242$ & $0.86(0.39), 238$ \\
\hline ANOVA & $\mathrm{F}=58.02, \mathrm{p}<.001, \eta^{2}=.15$ & $\mathrm{~F}=9.13, \mathrm{p}<.001, \eta^{2}=.03$ \\
\hline
\end{tabular}




\begin{tabular}{|l|l|l|}
\hline Serbia & Traditionalism scale & Household work division (women) \\
\hline Religiosity & $\mathrm{M}(\mathrm{SD}), \mathrm{N}$ & $\mathrm{M}(\mathrm{SD}), \mathrm{N}$ \\
\hline Scoring Lowest & $4.60(0.74), 266$ & $0.64(0.68), 259$ \\
\hline Scoring Mid-Low & $5.03(0.68), 233$ & $0.74(0.58), 231$ \\
\hline Scoring Mid-High & $5.06(0.71), 254$ & $0.76(0.52), 248$ \\
\hline Scoring Highest & $5.23(0.69), 244$ & $0.75(0.55), 239$ \\
\hline ANOVA & $\mathrm{F}=37.86, \mathrm{p}<.001, \eta^{2}=.10$ & $\mathrm{~F}=2.08, \mathrm{p}=.101, \eta^{2}=.01$ \\
\hline
\end{tabular}

In the following section, the correlations between religiosity, traditionalism, and division of housework (reporting that women are more frequently in charge of various household chores compared to men) are presented separately for men (Table 4) and women (Table 5). Among both men and women in Croatia and Serbia, religiosity correlated positively with traditionalism. People with high scores on the religiosity scale tended to have high scores on the traditionalism scale, which was in accordance with the results presented in Tables 2 and 3. Notably, in both Serbia and Croatia men's traditionalism correlated positively with reporting that women were more frequently in charge of various household chores. Among women, this correlation was non-significant. Furthermore, men's religiosity in Croatia correlated positively with reporting that women were frequently in charge of various household chores. This correlation among men in Serbia was in the same direction, although it did not reach statistical significance $(p=.085)$. Among women, the correlation between religiosity and reporting that women were frequently in charge of various household chores was not significant. To sum up, religiosity and traditionalism tended to correlate consistently in the two countries both among women and men. However, only among men did reporting that women were frequently in charge of various household work correlate positively with traditionalism (in both countries), as well as with religiosity (in Croatia).

Table 4. Correlations between traditionalism, religiosity, and division of household work among men

\begin{tabular}{|l|l|l|l|}
\hline Country & & Religiosity & Household work division (women) \\
\hline Croatia & Traditionalism & $.42^{* * *}$ & $.16^{* * *}$ \\
\hline $\mathrm{ns}=408-416$ & Religiosity & - & $.13^{* *}$ \\
\hline Serbia & Traditionalism & $.38^{* * *}$ & $.16^{* * *}$ \\
\hline $\mathrm{ns}=446-457$ & Religiosity & - & .08 \\
\hline
\end{tabular}

Note. $* * * p<.001 * * p<.010, * p<.05$ 
Table 5. Correlations between traditionalism, religiosity, and division of household work among women

\begin{tabular}{|l|l|l|l|}
\hline Country & & Religiosity & Household work division (women) \\
\hline Croatia & Traditionalism & $.44^{* * *}$ & -.01 \\
\hline ns $=576-584$ & Religiosity & - & .02 \\
\hline Serbia & Traditionalism & $.28^{* * *}$ & -.01 \\
\hline ns $=528-540$ & Religiosity & - & .01 \\
\hline
\end{tabular}

Note. $* * * p<.001$

\section{Additional confirmation of the theses}

To further investigate the relationship between religiosity and traditionalism, another dataset was analyzed, consisting of data compiled in 2017/2018 as part of the nationally representative survey $(\mathrm{N}=1210)$ GENMOD. The aim of the project was to study gender identities in post-transitional Croatia from the perspective of new theories of modernization and development. Since the data were collected only in Croatia, and not in Serbia, comparisons between the two countries are not possible.

In the GENMOD project, religiosity was measured as frequency of religious attendance, on a scale from 1 (more than once a week) to 7 (never or almost never). This item was reversely coded, so that higher numbers indicate a higher level of religiosity.

As a measure of the facet of traditionalism, specifically the traditionalist division of household work, the respondents' answers to two questions were studied: (1) On average, how many hours per week do you spend doing any household chores, including taking care of children, and (2) On average, how many hours per week does your partner or spouse spend doing any household chores, including taking care of children? The respondents provided answers on a scale from 1 ( 0 hours) to 7 (more than 40 hours).

Crucially, we analyzed the relationship between religiosity (frequency of attendance) and division of household work separately for the two genders. If religiosity were positively associated with a traditionalist division of household work, we would expect (1) a correlation between religiosity and the number of weekly hours that the respondent's partner spends on household work among the men, and (2) a correlation between religiosity and the number of weekly hours that the respondent herself spends on household work among the women. In other words, if there is a positive correlation between religiosity and traditionalism, 
we would expect that religiosity correlates with high numbers of hours that women spend on household activities among both women and men (Tomić-Koludrović et al. 2018).

Table 6. Correlations between frequency of religious attendance, and the perceived frequency of household work done by the respondent or the respondent's partner/spouse, separately for men and women (GENMOD data)

\begin{tabular}{|l|l|l|}
\hline & $\begin{array}{l}\text { Participant's Hours Spent } \\
\text { on Household Activities }\end{array}$ & $\begin{array}{l}\text { Partner's/Spouse's Hours } \\
\text { Spent on Household Activities }\end{array}$ \\
\hline & Men (ns $=550,292)$ & \\
\hline Religiosity (attendance) & .03 & $.12^{*}$ \\
\hline & Women $(\mathrm{ns}=619,334)$ & \\
\hline Religiosity (attendance) & $.17^{* * *}$ & .09 \\
\hline
\end{tabular}

Note. $* * * p<.001, * p<.05$

The results in Table 6 suggest that among both women and men, higher religiosity is related to a higher perception that women spend more hours per week on household activities. These results obtained from the GENMOD data support the SCOPES findings, suggesting that the relationship between high religiosity and traditionalism may be applied to the field of gender-based division of labor.

The data from this study also illustrate the fact that religiosity and traditionalism spill over into real life and support the asymmetric division of household work, which results in women being responsible for doing this type of work to a greater extent than men. At the same time, this additional analysis also shows that the noted patterns are perpetuated in the societies studied.

\section{Concluding remarks}

At the beginning of this analysis we expected to determine differences between the countries in terms of steps made towards modernity. We also expected that we would determine a lack of consistency between attitudes and practices. We considered that attitudes change more quickly, and that the attitudes in favor of gender equality had been to a great extent adopted during socialism, but also during the transition. We expected that it would be more difficult for practices to change, and that we would determine a traditional division of labor in the household which is contrary to modern attitudes. Our expectations were not realized. 
The occurrences which were studied showed a consistent connection along the religiosity-traditionality-household division of labor relation.

The countries that are the subject of this analysis, to a significant extent, underwent a revitalization of religiosity following the fall of socialism. However, certain differences do exist. Religiosity is, based on all the parameters studied (frequency of attendance of religious ceremonies, frequency of prayer, receiving strength and support from religion) greater in Croatia than in Serbia. ${ }^{9}$ Based on the complex scale which we utilized, we determined that traditionality is greater in Serbia. These findings indicate that the two occurrences need not necessarily be linked. In order to understand this occurrence we carried out additional analyses. They indicated that a statistically significant relation does exist between religiosity and traditionality. Therefore, we could expect of religious individuals to be traditional, and the greater their religiosity, the more traditional they were.

A consistent outcome of our research is that in both countries, among women as well as among men, there is a positive correlation between religiosity and traditionalism. However, the relation between the recognition of women as individuals responsible for household work on the one hand, and traditionalism and religiosity on the other, appears inconsistently among the groups which were studied. The correlations between religiosity and traditionalism, on the one hand, and the recognition of women as individuals responsible for household work on the other, are not statistically significant in the subsamples of women. This could indicate that women do not experience the Church as an institution which they can expect help from in everyday life (Tomić-Koludrović 2015, 235) and therefore opt for modernization, irrespective of their religiosity. It is possible that these results reflect the speed of the emancipation of women and men, which has been noted in some studies carried out in Croatia (Tomić-Koludrović et al. 2018, 141142). Still, the data from the second GENMOD project in Croatia indicate that the correlation between religiosity and the division of household work, that is, the fact that women are in charge of most household work, can be found among both men and women. It could be assumed that there is a certain dynamic in these relationships and that the retraditionalized attitudes to a certain extent clash with reality that is characterized by a higher level of gender equality in everyday life. However, the possibility of retraditionalization constantly continues to exert a certain potential in these societies.

9 The findings of the Pew institue point to the same conclusions (https://balkans.aljazeera. net/interactives/2019/2/9/mapa-religioznost-u-evropi-i-regiji) 
The dominant religious communities have a developed discourse on gender issues and advocate the perpetuation of the patriarchal model of gender. In the sociological school of thought in these countries there have been various evaluations of the actual impact of increased religiosity following the fall of socialism in various areas of social life and on the value orientations of citizens in Croatia and Serbia. It was noted that in some fields there is no real impact of religiosity on the moral views of the citizens, while it is significant in others. In the countries studied it is possible, to a significant extent, not to detect the impact of religiosity, for example, on work ethics and on other elements of public morality (Zrinščak et al. 2000, 252), while this impact has been detected in the field of gender relations (Baloban et al. 2014, Gavrilovic, 2013). ${ }^{10}$ In the case of the relationship between religiosity and traditionalism, previous findings have pointed to a certain independence to these processes; specifically in Croatia it was possible to detect "contradictions in experienced religiosity and 'distanced' ecclesiology" (Tomić-Koludrović 2015). At the same time, it was possible to detect an inconsistency between the level of religiosity and traditionalism. In Serbia, the level of traditionalism is greater, while in Croatia the level of religiosity is higher. Our findings, which have attempted to dig deeper into the understanding of these relationships, indicate that there is a correlation between religiosity, traditionalism, and practices pertaining to household work. Coherent traditional value orientations in Inglehart's sense were noted.

In the case of the division of household work, general trends can be noted according to which this work remains predominantly the occupation of women, even though some authors noted "evident steps in modernization to achieve equality" (Tomić-Koludrović et al. 2018). Our findings indicate that it is also the religiosity of people in Serbia and Croatia that supports the trend of traditionalism, considering the conditions of frequent exposure to the discourse of religious communities, despite the aforementioned steps towards modernization. These findings indicate the potential of religious communities to influence social events, especially in the field of gender relations, which are the focus of both the discourse and the activities of the dominant religious communities in Croatia and Serbia. This also suggests that policies meant to promote gender equality should also take the negative impact of religious communities into consideration.

Religiosity that is tied to the dominant religious communities and cultural matrices in these countries is linked to traditionality, and that is a well-known

10 Most of these analyses have been done on EVS data, and both of these countries participated in this study. 
fact. However, certain earlier studies which were cited in this paper pointed to possible steps being taken towards modernity, despite increased religiosity. Even though it is impossible to measure the precise impact of discourse and the activities of religious communities found in Croatia and Serbia on believers, it is clear that the level of religiosity is high and that the attitude of these religious communities is clearly stated. There is also a strong desire to impact social life, to create a social context in which traditional and patriarchal attitudes and practices are successfully maintained, which can, should the need arise, under the conditions of a constant "cultural defense" of the still tense relations in the region, be mobilized. This phenomenon is a fertile breeding ground for the further retraditionalization of these societies, as well as for the stopping or slowing down of the process of achieving gender equality in real social life. Despite the stated differences in these societies, there is still a high level of religiosity and activities of the religious communities is a "guarantee" of the conservation of patriarchal attitudes and the slowing down of modernization in the sphere of gender relations.

Further research should re-evaluate the relationship between the religiosity of women and their readiness to accept the stereotypical division of labor. At the same time, we should monitor whether the noted trend indicating decreasing levels of trust in the Church will have consequences for the relationship between religiosity, traditionalism, and the division of household work.

\section{Appendix}

Table 7. Items in the traditionalism scale

\begin{tabular}{|l|c|}
\hline Traditionalism & Scale \\
\hline The personal importance of... & \\
\hline Following traditional customs & $1-7$ \\
\hline Obeying the law and order & $1-7$ \\
\hline Achieving maximum security in life & $1-7$ \\
\hline Working for the welfare of my nation & $1-7$ \\
\hline Promoting the values of my religion & $1-7$ \\
\hline Having a lot of children & $1-7$ \\
\hline Always fulfilling one's duties & $1-7$ \\
\hline Justification of... & \\
\hline Suicide & $1-10$ \\
\hline Homosexuality & $1-10$ \\
\hline Abortion & $1-10$ \\
\hline Divorce & $1-10$ \\
\hline Agreeing with the following statements... & \\
\hline $\begin{array}{l}\text { In the case of high unemployment, men should have the advantage of em- } \\
\text { ployment over women. }\end{array}$ & $1-5$ \\
\hline
\end{tabular}


Employers in [my country] should give priority to [my country's] citizens when hiring

If a woman earns more than her husband, family problems are possible. $1-5$

Women should play a greater role in leadership positions in society, the business world, culture, and politics. (R)

A young child will be sure to suffer if the mother is employed.

$1-5$

Table 8. Items in the religiosity scale

\begin{tabular}{|l|c|}
\hline Religiosity & Scale \\
\hline Agreeing with ... & \\
\hline I receive strength and support from my religion & $1-10$ \\
\hline Frequency of ... & \\
\hline Attending religious ceremonies & $1-6$ \\
\hline Prayer & $1-6$ \\
\hline
\end{tabular}

Table 9. The full list of household chores, some of which were used in the division of household work by gender variable.

\begin{tabular}{|l|}
\hline Housework-Related Chores \\
\hline *Buying Groceries \\
\hline *Washing the Dishes \\
\hline *Vacuuming \\
\hline Taking Care of the Pets \\
\hline Gardening \\
\hline *Wpring cleaning \\
\hline *Ironing the Windows \\
\hline Carpet Shaking and Washing \\
\hline Plumbing Repairs in the House \\
\hline Painting the Walls \\
\hline Repairing Household Appliances \\
\hline Washing the Car \\
\hline Fixing the Car \\
\hline *Washing the Laundry \\
\hline *Cooking \\
\hline Taking Care of the Senior Members of the Household \\
\hline Taking the Children to the Kindergarten/School \\
\hline Studying and Homework with the Children \\
\hline Taking the Children Outside to Play \\
\hline
\end{tabular}




\section{Funding}

This work has been supported in part by the Croatian Science Foundation under the project "Relational Gender Identities in Croatia: Modernization and Development Perspectives" (GENMOD) number HRZZ-IP-2016-06-6010, and is also a part of the project "The development of a multidimensional research model of social inequality" financed by the Ministry of Science and Education of the Republic of Croatia and the Ministry of Education, Science and Technological Development of the Republic of Serbia (2019 - 2021).

\section{References}

Anić, Rebeka. 2004. Die Frauen in der Kirche Kroatiens im 20. Jahrhundert. Wien: Lit Verlag.

Anić, Jadranka R. 2017. "Die Anti-Gender-Bewegungin Kroatien. Einnationales Phiinomen transnational beeinflusst." In Genderstudieren. Lernprozess fur Theologieund Kirche, edited by Margit Eckholt, 413-433. Ostfildern: Grünewald.

Anić, Jadranka R. 2019. “Die 'anthropologische Revolutio' - Zerstörung oder Befreiung der christlichen Anthropologie?” In Identitäre Versuchungen. Identitäts ver handlungen zwischen Emanzipation und Herrschaft; Identitary Temptations. Identity Negotiations between Emancipation and Hegemony, edited by Judith Gruber, Sebastian Pittl, Stefan Silber and Christian Tauchner, 215-224. Aachen: Verlag Mainz.

Baloban, Josip, Krunoslav Nikodem and Siniša Zrinščak. 2014. Vrednote u Hrvatskoj i u Europi. Komparativna analiza. Zagreb: Kršćanska sadašnjost and Katolički bogoslovni fakultet Sveučilišta u Zagrebu.

Barišić, Marin. 2016. "Božić 2016. - Danja misa." December 25, 2016. Accessed January 23, 2020. https://smn.hr/propovijedi-2/bozicne-propovijedi/2428-bozic-2016-danja-misa

Barišić, Marin. 2017. "Uskrsna poruka - 2017.” April 11, 2017. Accessed January 5, 2020. https://smn.hr/poruke-2/uskrsne-poruke/2569-uskrsna-poruka-2017

Barišić, Marin. 2017a. "Mala Gospa - Solin - 2017." September 7, 2017. Accessed January 4, 2020. https://smn.hccessed/propovijedi-2/blagdan-male-gospe/2812-mala-gospa-solin-2017

Barišić, Marin. 2017b. "Godina majčinstva. Proglas svim vjernicima u Splitsko-makarskoj nadbiskupiji u pripravi za Treći nacionalni susret hrvatskih katoličkih obitelji u Solinu 2018., pod geslom: 'Očinstvo i majčinstvo: dva lica roditeljskog poslanja'.” November 27, 2017. Accessed January 5, 2020. https://smn.hr/poruke-2/ okruznice-i-druga-pisma/2968-godina-majcinstva

Barišić, Marin. 2017c. "Božić 2017. - Misa ponoćka." December 25, 2017. Accessed March 5, 2020. https://smn.hr/propovijedi-2/bozicne-propovijedi/3044-bozic-2017-misa-polnocka 
Barišić, Marin. 2017d. "Božić 2017. - Danja misa.” December 25, 2017. Accessed January 3, 2020. https://smn.hr/propovijedi-2/bozicne-propovijedi/3043-bozic-2017-danja-misa

Barišić, Marin. 2018. “Uskrsna poruka - 2018.” March 27. 2018. Accessed January 5, 2020. https://smn.hr/poruke-2/uskrsne-poruke/3191-uskrsna-poruka-2018

Bartkowski. John. P. 2007. "Religious Socialization among American Youth: How Faith Shapes Parents, Children, and Adolescents." In The Sage Handbook of the Sociology of Religion, edited by James Beckfordand N. and Jay Demerath III, 51125. London: Sage.

Bekić, Janko. 2013. “Zdravstveni odgoj na raskrižju politike moralnosti i politike identiteta." Političke analize 4, no. 16: 19-23.

Bozanić, Josip. 2013. "Kardinalova homilija prigodom svetkovine sv. Antuna Padovanskog.” June 24. 2013, Accessed January 3, 2020. http://www.zg-nadbiskupija.hr/ dokumenti/rijec-nadbiskupa/kardinalova-homilija-prigodom-svetkovine-sv-antuna-padovanskog

Blagojević, Mirko. 2009. "Revitalizacija religije i religioznosti u Srbiji: stvarnost ili mit?" Filozofija i društvo 20, no. 2: 97-117.

Blagojević, Mirko. 2011. Orthodoxy from an Empirical Perspective. Belgrade: Institute for Philosophy and Social Theory and Niš: Yugoslav Society for the Scientific Study of Religion.

Bruce, Steve. 1996. Religion in the Modern World. From Cathedrals to Cults. New York: Oxford University Press.

Butcher, Brian A. 2020. "Gender and Orthodox theology." In Orthodox Christianity and Gender. Dynamics of tradition, culture and lived practice, edited by Helena Kupari and Elina Vuola, 25-46. Abingdon: Routledge,

Črpić, Gordan and Siniša Zrinščak. 2010. "Dinamičnost u stabilnosti: religioznost u Hrvatskoj 1999. i 2008. godine.” Društvena istraživanja, 19, no. 1-2: 3-27.

D. I. 2018. "Svećenik odbija pričestiti one koji su glasali za ratifikaciju Istanbulske, Nadbiskupija se ograđuje: 'To je njegov privatni stav'." April 16, 2018. Accessed December 14. 2019. https://dnevnik.hr/vijesti/hrvatska/dok-se-ne-pokaju-za-sramotan-cin-svecenik-odbija-pricestiti-one-koji-su-glasali-za-ratifikaciju-istanbulske---513849.html

Državni zavod za statistiku. 2011. Stanovništvo prema narodnosti i vjeri. Popis 2011. Accessed February 6, 2020. https://www.dzs.hr/hrv/censuses/census2011/results/ htm/H01_01_12/H01_01_12.html

Dugalić, Vlatko. 2007. "Politička traganja Crkve u Hrvatskoj (1989-2007)." Bogoslovska smotra 77, no. 2: 483-539.

Đorđević, Mirko. 2005. “Iskušenja klerikalizacije.” Republika, 352-353, March 1-31, 2005, http://www.republika.co.rs/352-353/20.html

Đorić, Gorana and Danijela Gavrilović. 2006. "Between pro-natalist population policy and women's reproductive rights: The analysis of exposure of the two discourses in press media after 2000." Sociologija 48, no. 1: 73-95.

Djurić-Milovanović, Aleksandra and Radmila Radić. 2019 "Women in the Serbian Orthodox Church: Historical Overview and Contemporary Situation.” Occasional Pa- 
pers on Religion in Eastern Europe, 39, no. 6 (January): 1-29. https://digitalcommons.georgefox.edu/ree/vol39/iss6/2

Gavrilović, Danijela. 2013. Doba upotrebe: religija i moral u savremenoj Srbiji. Niš: Filozofski fakultet.

Gavrilović, Danijela and Dragoljub B. Đorđević. 2018. "Religionization of Public Space: Symbolic Struggles and Beyond - The Case of Ex-Yugoslav Societies." Religions 9, no. 36: 1-10.

Goldberger, Goran. 2005. "Revitalizacija religije u sjeni naslijeđa liberalne zakonske regulative: stavovi o pobačaju." Sociologija sela 43, no. 2: 409-437.

Hodžić, Amir and Aleksandar Štulhofer. 2017. "Embryo, teddybear-centaur and the constitution: Mobilizations against 'gender ideology' and sexual permissiveness in Croatia.” In Anti-Gender Campaigns in Europe. Mobilizing against Equality, edited by Roman Kuhar and David Paternotte, 59-77. London and New York: Rowman \& Littlefield Publishers.

Hughson, Marina. 2018. Muškarci u Srbiji: promene, otpori, izazovi - Rezultati istraživanja o muškarcima i rodnoj ravnopravnosti. IMAGES Srbija 2018. Beograd: Centar E8.

Ika (2020), "Predavanje dr. Asje Palinić Civtanović na temu 'Tko upravlja našom bračnom srećom?'.” February 7, 2020. Accessed February 7, 2020. https://ika.hkm. $\mathrm{hr}$ /splitsko-makarska-metropolija/predavanje-dr-asje-palinic-cvitanovic-na-temu-tko-upravlja-nasom-bracnom-srecom/ (7.2.2020)

Inglehart, Ronald and Wayne E. Baker. 2000. "Modernization, Cultural Change, and the Persistence of Traditional Values.” American Sociological Review 65, no. 1: 1951.

Jovanović, Miloš. 2011. "Moralistička osuda homoseksualnosti u pravoslavlju." Teme 35, no. 3: 705-744.

Jovanović, Miloš and Danijela Gavrilović. 2012. "Trust and Legitimation - The Case of Serbia." In Social and Cultural Capital in Western Balkan Societies, edited by Predrag Cvetičanin and Ana Birešev, 133-144. Niš: Centre for Empirical Cultural Studies of South-East Europe; Belgrade: The Institute for Philosophy and Social Theory of the University of Belgrade.

Krstić, Nemanja, Jasmina Nedeljković and Danijela Gavrilović. 2016. "Vrednovanje porodice u svetlu religioznosti - komparativna analiza istočnoevropskih društava." Religija i tolerancija 14, no. 26: 209-224.

Kuhar, Roman and David Paternotte. 2017. Anti-Gender Campaigns in Europe. Mobilizing against Equality. London and New York: Rowman \& Littlefield.

Kupari, Helena and Elina Vuola. 2020. "Introduction.” In Orthodox Christianity and Gender. Dynamics of tradition, culture and lived practice, edited by Helena Kupari and Elina Vuola. Abingdon: Routledge.

Leinert-Novosel, Smiljana. 1999. Žena na pragu 21. stoljeća. Između majčinstva i profesije. Zagreb: Ženska grupa TOD and EDAC.

Lüdecke, Norbert. 2009. "Mehr Geschlechtals Recht? Zur Stellungder Fraunach Lehreund Rechtderrömisch-katholischen Kirche.” In ,... männlich und weiblich schuf 
er sie ."(Gen 1,27): Zur Brisanzder Geschlechterfragein Religionund Gesellschaft, editet by Sigrid Eder, and Irmtraud, 183-216. Innsbruck: Tyrolia.

Mapa religioznost u Evropi i regiji, February, 09, 2019. Accessed April 20, 2021. https:// balkans.aljazeera.net/interactives/2019/2/9/mapa-religioznost-u-evropi-i-regiji)

Marinović, Ankica. 2017. "Neugodni mirisi ateizma: jedan aspekt hrvatske obrazovne stvarnosti." In Dvadeset pet godina hrvatske neovisnosti - kako dalje? edited by Tvrtko Jakovina, 397-414. Zagreb: Centar za demokraciju i pravo Miko Tripalo.

Marinović Bobinac, Ankica. 2005. "Dimenzija religioznog iskustva u Hrvatskoj: ,šapat anđela' iz sociologijske perspektive.” Sociologija sela 43, no. 2: 339-370.

Miriano, Costanca. 2017. Udaj se i budi podložna. Ekstremna vježba za neustrašive žene. Zagreb: Glas Koncila.

Miriano, Costanca. 2017. Oženi se i umri za nju. Pravi muškarci za žene bez straha. Zagreb: Glas Koncila.

Nikodem, Krunoslav and Siniša Zrinščak. 2019. "Između distancirane crkvenosti i intenzivne osobne religioznosti: religijske promjene u hrvatskom društvu od 1999. do 2018. godine." Društvena istraživanja 28, no. 3: 371-390.

Papa Franjo (2016). Amoris Laetitia. Radost ljubavi. Zagreb: Kršćanska sadašnjost.

Peunić, Martina. 2019. Marksistička ishodišta suvremene rodne ideologije. Thesis. Accessed December 6, 2020. https://repozitorij.djkbf.hr/islandora/object/djkbf\%3A184

Pralica, Dejan (2006). "Religijski i ideološki diskurs u poslanicama Srpske pravoslavne crkve." Religija i tolerancija - naučni časopis 4, no. 5: 41-52.

Radić, Radmila and Milan Vukomanović. 2014. "Religion and Democracy in Serbia since 1989: The Case of the Serbian Orthodox Church." In Religion and Politics in Post-Socialist Central and Southeastern Europe, edited by Sabrina P. Ramet, 180211. Palgrave Macmillan.

Ranković, Ljubomir. 2009. Žena ikona crkve i blago sveta. Šabac: Glas Crkve.

Sekulić, Duško. 2011. "Vrijednosno-ideološke orijentacije kao predznak i posljedica društvenih promjena." Politička misao 48, no. 3: 35-64.

Simić, Žikica, (2014) Diskurs Srpske pravoslavne crkve o ženi i njen položaj u društvu. (Thesis). Accessed December 6, 2020. http://nardus.mpn.gov.rs/handle/123456789/4004

Stjepanović-Zaharijevski, Dragana and Danijela Gavrilović. 2010. "Identiteti i porodične vrednosne orijentacije na Balkanu." Sociologija 52, no. 1: 23-40.

Šikić-Mićanović, Lynette. 2012. Skriveni životi. Prilog antropologiji ruralnih žena. Zagreb: Institut Ivo Pilar.

Šta treba da zna svaki pravoslavni dečak. Kragujevac: Svetigora, 2000.

Šta treba da zna svaka pravoslavna devojčica. Kragujevac: Svetigora. 2000.

Tomić-Koludrović, Inga and Suzana Kunac. 2000. Rizici modernizacije: žene u Hrvatskoj devedesetih. Split: Udruga građana „Stope nade“.

Tomić-Koludrović, Inga and Mirko Petrić. 2007. "Hrvatsko društvo - prije i tijekom tranzicije”. Društvena istraživanja 16, no. 4-5: 867-889.

Tomić-Koludrović, Inga. 2015. Pomak prema modernosti. Žene u Hrvatskoj u razdoblju „zrele“ tranzicije. Zagreb: Jesenski i Turk. 
Tomić-Koludrović, Inga, Mirko Petrić, Ivan Puzek and Željka Zdravković. 2018. Rodni stavovi i prakse u Hrvatskoj. Izvještaj o kvantitativnim rezultatima projekta GENMOD. November 28, 2018. Accessed December 6, 2020. https://www.pilar. hr/wp-content/uploads/2019/11/ISP_Izvje\%C5\%A1taj_o_kvantitativnim_rezultaima.pdf

Vasilevich, Natallia. (2018). "Frauen ordination in der orthodoxen Kirche. Wird die Diakoninnenweihe im Patriarchat von Alexandriender Flügelschlagdes Schmetterlings?” In Frauen in kirchlichen Ämtern. Reformbewegungen in der Ökumene, edited by Margit Echolt, Ulrike Link-Wieczorek, Dorothea Sattler and Andrea Strübind, 261-272. Freiburg im Breisgau: Herder.

Veroispovest, maternji jezik i nacionalna pripadnost, Popis stanovništva, domaćinstava i stanova 2011. Republički zavod za statistiku RS. Accessed November 5, 2020. https:/ezproxy.nb.rs:2224/pb-assets/cmscontent/CRR/CRR\%20style\%20guide\%202018-1536920244270.pdf

Vrcan, Srđan. 2001. Vjera u vrtlozima tranzicije. Split: Dalmatinska akcija.

Vujadinović, Dragica and Vojislav Stanimirović. 2017. "Rodni odnosi u Srbiji u doba tranzicije - između emancipacije i retradicionalizacije". In Studije roda, edited by Dragica Vujadinović and Vojislav Stanimirović. Beograd: Pravni fakultet.

Vukomanović, Milan. 2008. Homo viator: religija i novo doba. Beograd: Čigoja štampa. Vukomanović, Milan. 2011. "Serbian Orthodox Church Between Traditionalism and Fundamentalism". In Fundamentalism in the Modern World, Vol 1, edited by Ulrika Mårtensson, Jennifer Bailey, Priscilla Ringrose, Asbjørn Dyrendal, 148-170. London: I. B. Tauris.

Štuhec, Ivan Janez. 2014. "Sekularna Europa i novo pozicioniranje religije u društvu". Nova prisutnost 12, no. 1: 5-22.

Ugovor o suradnji u području odgoja i kulture (1997). Accessed December 6, 2020. http://hbk.hr/ugovor-o-suradnji-na-podrucju-odgoja-i-kulture/

Ugovor o gospodarskim pitanjima (1998). Accessed December 6, 2020. http://hbk.hr/ ugovor-o-gospodarskim-pitanjima/

Ustav republike Srbije, 2006. Accessed December 6, 2020. http://www.parlament.gov.rs/ upload/documents/Ustav_Srbije_pdf.pdf

Zakon o crkvama i verskim zajednicama RS, 2006. Accessed December 6, 2020. https:// www.paragraf.rs/propisi/zakon_o_crkvama_i_verskim_zajednicama.html

Zaharijević, Adriana (2018) Dženderizam nesting in Serbia, Accessed October 8, 2018. https://blogs.lse.ac.uk/gender/2018/10/08/dzenderizam-nesting-in-serbia/

Zrinščak, Siniša, Gordan Črpić and Stjepan Kušar. (2000). "Vjerovanje i religioznost." Bogoslovska smotra 70, no. 2: 233-255. 


\title{
Danijela Gavrilović
}

Univerzitet u Nišu, Filozofski fakultet

danijela.gavrilovic@filfak.ni.ac.rs

Jadranka Rebeka Anić

Institute of Social Sciences Ivo Pilar

Regionalni Centar Split, Hrvatska

Filip Užarević

Institute of Social Sciences Ivo Pilar

Zagreb, Hrvatska

\section{Ivan Puzek}

Univerzitet u Zadru, Odsek Sociologije

Hrvatska

\section{KORELACIJA RELIGIOZNOSTI I TRADICIONALNOSTI U OBLASTI RODNIH ODNOSA U HRVATSKOJ I SRBIJI}

\begin{abstract}
Rezime
U ovom tekstu analiziramo povezanost diskursa dominantnih religijskih zajednica - Katoličke Crkve u Hrvatskoj i Srpske pravoslavne crkve u Srbiji-i stavova i praksi stanovnika ovih postsocijalističkih zemalja. Da bi se proverila ova teza kompariraju se empirijski podaci koji se odnose na nivo religioznosti, tradicionalnosti i rodne podele rada. Naši nalazi pokazuju da i u Hrvatskoj i u Srbiji postoji korelacija između religioznosti i tradicionalnosti, naime, religiozniji ljudi su i tradicionalniji. Korelacija postoji i sa podelom rada u domaćinstvu, ali se pojavljuju neke specifičnosti u pogledu odnosa muškaraca $i$ žena prema podeli rada.
\end{abstract}

Ključne reči: religioznost, tradicionalnost, rodna podela rada 